\title{
A IMPORTÂNCIA DO RACIOCÍNIO RETÓRICO-TÓPICO PARA UMA MELHOR COMPREENSÃO DA DINÂMICA DA ARGUMENTAÇÃO JURÍDICA NA CONTEMPORANEIDADE
}

\author{
Andreas Joachim Krell ${ }^{1}$ \\ Olga Jubert Gouveia Krell ${ }^{2}$
}

\section{Resumo}

Este artigo se propõe a investigar a origem e a importância do raciocínio retórico-tópico, que pode levar a uma melhor compreensão dos processos de criação das decisões jurídicas na atualidade. Através do estudo da retórica, que se ocupa das maneiras como um discurso é capaz de persuadir um auditório sobre determinado assunto, e da tópica, que visa a solucionar problemas com ajuda de argumentos respaldados no senso comum ou na opinião das autoridades, é possível superar a ideia da decisão jurídica como resultado do raciocínio dedutivo mediante a subsunção de fatos a normas gerais. A partir das lições de Aristóteles é apresentado um quadro do significado atual da retórica e da tópica, com ênfase em autores como Viehweg, Perelman, Ballweg, Schlieffen, Kriele, Wieacker, Adeodato. Pretende-se despertar o interesse para realizar estudos adicionais sobre a matéria, com o fim de criar uma visão mais reflexiva e crítica dos operadores do Direito sobre o seu ofício. Um pensamento inspirado na retorica e na tópica ajuda também a entender melhor a produção de decisões jurídicas nos órgãos estatais no Brasil, onde ainda não se formou um "padrão hermenêutico mínimo" que torne mais racionais e previsíveis os atos de interpretação e aplicação do Direito.

Palavras-chave: Retórica; tópica; argumentação; silogismo; entimema.

\section{INTRODUÇÃO}

Os conceitos retórica e tópica ainda são pouco presentes no ensino jurídico brasileiro. Alguns livros de Introdução ao Direito, Filosofia do Direito ou História do Direito, apesar de explicá-los, dificilmente os colocam numa relação direta com a compreensão e aplicação do Direito contemporâneo, especialmente para sustentar uma atitude crítica em relação à visão tradicional de uma interpretação que funcionaria através da "subsunção" dos fatos aos termos legais. Vale frisar que desde 2009 o tema da "superação dos métodos de interpretação mediante

\footnotetext{
${ }^{1}$ Doctor Juris pela Freie Universität Berlin, Professor Associado de Direito Ambiental e Constitucional nos Cursos de Graduação e Mestrado em Direito da Univ. Federal de Alagoas, Pesquisador bolsista do CNPq (PQ-1B), consultor da CAPES. E-mail: akrell@uol.com.br

${ }^{2}$ Doutora em Direito Público pela Faculdade de Direito do Recife (UFPE), Professora Adjunta de Sociologia do Direito nos Cursos de Graduação e Mestrado em Direito da Univ. Federal de Alagoas, Coordenadora do Núcleo de Pesquisa (NPE). E-mail: olgajgk@uol.com.br
} 
puro raciocínio lógico-dedutivo" é assunto obrigatório nas provas de concurso público para a magistratura em nível nacional. ${ }^{3}$

Justamente a retórica e a tópica são formas de pensar que justificam a superação da visão lógico-formal do raciocínio jurídico, fornecendo subsídios valiosos para uma construção argumentativa da solução de casos no âmbito da interpretação e aplicação do Direito. Pode-se afirmar que a tópica faz parte da retórica, servindo a esta, como veremos adiante. Assim, o estudo sobre a origem, o conteúdo e os efeitos da retórica e da tópica pode ajudar bastante para explicar melhor o uso (ou a falta) de argumentos adequados na motivação das decisões dos órgãos públicos, especialmente dos tribunais.

Para muitos, o adjetivo "retórico" assinala, até hoje, a característica de um discurso que não apresenta bons argumentos para uma fundamentação material, mas consegue convencer os ouvintes em virtude de uma oratória bem planejada e executada, valendo-se de "truques" semânticos e outros meios de manipulação discursiva. Esta definição de retórica, porém, não explica satisfatoriamente o significado do termo, ainda que seja o objetivo primordial da retórica fornecer subsídios e critérios para convencer os ouvintes ou leitores de um discurso dos argumentos nele utilizados.

Uma visão mais retórica (e tópica) do Direito pode levar ao questionamento do próprio paradigma lógico-formal de sua "cientificidade", que tem a sua origem nas ciências naturais e continua influenciando fortemente as ciências humanas e sociais aplicadas. Na verdade, é difícil acreditar em uma "ciência do Direito" enquanto há cada vez mais decisões divergentes e até contraditórias tomadas pelos tribunais (até pelo STF e STJ), que, muitas vezes, julgam casos (quase) idênticos de forma diferente, com base nos mesmos textos legais. Em geral, a atuação diária dos operadores do Direito no Brasil é caracterizada pela falta de padrões hermenêuticos mais apurados e pela ausência de uma dogmática sofisticada que guie os intérpretes/aplicadores dos textos legais nos casos concretos.

Ao mesmo tempo, o estudo de figuras retóricas e tópicas no discurso jurídico falado e escrito pode revelar levar a inadequação do uso do termo verdade no campo da produção da decisão jurídica, sem que isso leve, necessariamente, à ideia de que os resultados deste processo interpretativo sejam meramente opinativos, subjetivos, aleatórios. Pelo contrário, o estudo da retórica e tópica fortalece ajuda a formar uma posição crítica em relação a teorias relativistas que defendem a contingência absoluta das decisões no âmbito do Direito.

Nas últimas décadas, a metodologia jurídica voltou a se aproximar da dimensão retórica do Direito. Como a retórica é a técnica de criar concordância, ela representa no âmbito jurídico os meios que o operador (juiz, promotor, procurador, advogado) utiliza para conseguir a aprovação dos colegas em relação à posição

${ }^{3} \mathrm{O}$ art. 47, I, da Res. 75 do CNJ, de 12.5.2009, prescreve que as provas de concurso público para a magistratura devem versar sobre "Noções gerais de Direito e formação humanística" (Anexo VI), dos quais faz parte a Filosofia do Direito (letra D), inclusive o item temático "Interpretação do Direito. A superação dos métodos de interpretação mediante puro raciocínio lógico-dedutivo. $\mathrm{O}$ método de interpretação pela lógica do razoável." 
defendida, seja ela comunicada oralmente ou por escrito. Especialmente nos casos mais difíceis, o sistema jurídico não permite apenas uma única solução deduzível das normas vigentes através do uso dos métodos de interpretação. Muitos termos empregados em textos legais são ambíguos e vagos, possibilitando diferentes enquadramentos dos fatos concretos, de acordo com a valoração do respectivo aplicador.

Igualmente variam bastante as opiniões doutrinárias sobre o tratamento adequado dos problemas que surgem no trabalho diário dos operadores do Direito; muitas decisões judiciais apontam em direções dogmáticas opostas. Aqui se abre um espaço para a prática retórica que pode orientar o aplicador do Direito na sua argumentação em favor de certa solução. A preferência dada à determinada interpretação do Direito sempre deve ser justificada. A cultura jurídica exige que a solução a ser considerada correta seja a mais razoável possível ou, pelo menos, plausível e, por isso, capaz de convencer os outros integrantes da comunidade jurídica.

Até hoje, a referência à arte de falar ilumina o aspecto essencial de que não basta ter um direito para que o mesmo também seja realizado em juízo. O critério final para que uma decisão jurídica seja considerada "correta" é o alcance de um (relativo) consenso sobre a questão se a solução esteja de acordo com a lei e o Direito. Por isso, a argumentação jurídica sempre deve se empenhar a conquistar o consentimento do outro, seja ele o parceiro contratual, o juiz, o administrador, o colega parlamentar ou o cidadão (GAST, 2006).

Não é mais aceitável a alegação de que os juízos de valor, que guiam todo o processo de interpretação e aplicação do Direito, seja apenas uma questão ligada aos impulsos, emoções e interesses de cada julgador, que escapam a qualquer controle da ordem jurídica. O estudo da tópica "aumenta os meios intelectuais de que o juiz dispõe na busca de uma solução razoável, aceitável e equitativa” (PERELMAN, 2004, p. 130, 135).

\section{AS ORIGENS CLÁSSICAS DA RETÓRICA; O ENTIMEMA COMO "SILOGISMO RETÓRICO”}

Como a filosofia normalmente é vista como "busca da verdade", a inclusão da retórica no seu âmbito é problemática, já que esta não se interessa pelo verdadeiro ou essencial das coisas, mas, ao contrário, pela conjectura e pelo opinativo. A retórica indaga sobre as formas de persuadir e convencer ${ }^{4}$ as pessoas de algo através da linguagem, sendo sua meta provocar ou aumentar a adesão de um auditório a certas teses (ADEODATO, 2009, p. 15ss.). Neste sentido, Perelman vê o seu objeto no "estudo das técnicas discursivas que visam a provocar ou a aumentar a adesão das mentes às teses apresentadas a seu assentamento" (PERELMAN, 2004, p. 141).

Aristóteles foi o primeiro filosofo ocidental que tratou a retórica como uma área de estudo e conhecimento. Para ele, as técnicas retóricas e dialéticas eram indispensáveis "para examinar e expor de uma forma

\footnotetext{
${ }^{4}$ A respeito da questão da diferença entre os termos persuadir e convencer, há quem defenda que "a persuasão acrescentaria à convicção a força necessária que é a única que conduzirá à ação" (cf. PERELMAN, 1999, p. 59ss., 70).
} 
racional os problemas referentes aos valores" (PERELMAN, 1999, p. 178). Além disso, a retórica tinha de ser subordinada à ética e não apenas buscar o sucesso estratégico da aprovação de um discurso, como defendiam os sofistas (ADEODATO, 2011, p. 298s.).

Aristóteles enfatizou que afirmações opinativas (endoxa) não poderiam ser chamadas de "verdadeiras", uma vez que, quando tratamos de temas vagos por natureza como "ações boas e justas" e bens, isto é, falando "de coisas que são verdadeiras apenas em linhas gerais, partindo de premissas do mesmo gênero, não devemos aspirar a conclusões mais precisas", já que seria possível "buscar a precisão em cada classe de coisas somente até onde a natureza do assunto permite". Por isso, ele julgava insensato "exigir de um orador demonstrações rigorosas", da mesma forma como seria "aceitar raciocínios apenas prováveis de um matemático" (ARISTÓTELES, 2001, p. 18 - n. 1.094b).

O silogismo é tido como um dos mais importantes legados do Aristóteles. Para ele, a lógica (ou analítica) é o método para se obter os "verdadeiros" silogismos, os apodíticos; já a dialética serve para produzir silogismos que passam por verdadeiros ou são aceitos como tais. Além disso, ele distingue entre os erísticos, ${ }^{6}$ que respeitam a forma do silogismo, mas têm conteúdo não verdadeiro, e os silogismos sofísticos, nos quais a forma é falsa, porém parece correta (SCHOPENHAUER, 1997, p. 195s.).

Entre os diferentes estágios de produção do discurso, o materialmente decisivo é a inventio, ${ }^{7}$ na qual é criada a plausibilidade dos argumentos utilizados e são reveladas as "boas razões" bem como o meio de agir adequado na justificação de juízos de valor (TAMMELO, 1971). Por isso, a retórica não pode ser reduzida à análise formal de figuras linguísticas, mas envolve também o conteúdo argumentativo, que o orador quer transmitir. Ao lado da "retórica-ornamento", concentrada nas estratégias para influir na opinião dos outros, há sempre uma "retórica-tópica", que é "uma teoria da argumentação de estrutura entimemática" (ADEODATO, 2009, p. 28s., 31).

O entimema foi chamado de silogismo retórico e também dialético: ${ }^{8}$ enquanto o silogismo lógico

\footnotetext{
${ }^{5}$ Para uma melhor compreensão dos diferentes elementos e dimensões da retórica, sua relação com os sofistas e da diferença entre as retóricas formal e material, recomenda-se a leitura do capítulo introdutório "Retórica como metódica para estudo do direito", da obra A retórica constitucional (p. 15-45), de autoria de J. M. Adeodato (2009).

${ }^{6} \mathrm{Na}$ argumentação erística o orador aproveita a ignorância ou o despreparo do ouvinte para convencê-lo de afirmações contraditórias, indignas de crédito ou simplesmente falsas (cf. ADEODATO, 2011, p. 306).

${ }^{7}$ As outras etapas do discurso são a dispositio (organização das informações), elocutio (adequação do pensamento às formas de expressão), memoria (retenção de informações) e pronuntiatio (postura e elegância no falar ou escrever); cf. ADEODATO, 2009, p. 17, 27s. Esta subdivisão se deve a Marcus Tullius Cicero (106-43 a. C.), político, orador e filósofo romano e, ao lado de Aristóteles, o maior teórico da retórica na história da civilização ocidental; sua principal obra sobre o tema é Rhetórica ad Herennium.

${ }^{8}$ Ainda que Aristóteles situasse a retórica - ao contrário da dialética - mais no contexto da oratória, alheia a perguntas e respostas, os limites destes termos são flutuantes. Adeodato explica que a definição do filósofo de silogismo dialético é praticamente a mesma que ele dá para o silogismo retórico, ainda que não use as expressões como sinônimas. As premissas do silogismo dialético não são qualificáveis como verdadeiras ou falsas, mas partem de opiniões geralmente aceitas e se valem de catálogos de topoi. Já o silogismo vol.09, n. 01, Rio de Janeiro, 2016.pp. 244-271 
pretende levar ao verdadeiro ou certo, o entimema baseia-se no provável ou verossímil, pois suas premissas, os endoxa, são proposições que apenas parecem verdadeiras a todos, aos mais sábios ou à maioria destes. $\mathrm{O}$ entimema, já na Antiguidade ligado à investigação de contradições no discurso judicial, não era considerado apenas uma forma de argumentação sem muita rigidez lógica, mas tido como um tipo de silogismo, ainda que incompleto, abreviado e imperfeito. Para Aristóteles, são justamente os topoi que servem para fundamentar os entimemas; segundo ele, "o entimema é o núcleo da persuasão e o objeto central da retórica" (ADEODATO, 2002, p. 266ss.).

É notório que o silogismo lógico-dedutivo não é o procedimento efetivamente utilizado para atingir as decisões jurídicas pronunciadas por órgãos estatais, mas serve, sobretudo, para apresentar, de maneira funcional e legitimadora, uma decisão obtida por outros meios. Este "silogismo jurídico" é empregado apenas para a justificação interna da decisão, na qual se verifica se ela segue logicamente as premissas expostas. Diferentemente, o objeto da justificação externa é a fundamentação destas premissas, que não se dá pela inferência lógica, mas por meio de uma argumentação racional (ALEXY, 2011).

A própria estrutura da argumentação judicial é muito mais entimemática do que silogística, uma vez que parte das premissas da conclusão normalmente é mantida em silêncio. Reconhecer este fato ajuda a desenvolver uma postura crítica em relação às bases pretensamente "científicas" do Direito contemporâneo, como a neutralidade do juiz, a unidade do ordenamento, a dedução da decisão jurídica de uma norma geral prévia etc., as quais, no fundo, não passam de "meras estratégias discursivas" (ADEODATO, 2002, p. 261s., 271, 281ss.).

De acordo com Aristóteles (2005, p. 96s.), um discurso é capaz de persuadir por três meios: o caráter moral da pessoa do orador, que dá peso a suas palavras (ethos), a sua capacidade de despertar emoções nos ouvintes (pathos) e a demonstração racional e objetiva a partir do próprio discurso (logos). Diz ele:

Persuade-se pelo caráter quando o discurso é proferido de tal maneira que deixa a impressão de o orador ser digno de fé. (...) persuade-se pela disposição dos ouvintes quando estes são levados a sentir emoção por meio do discurso, pois os juízos que emitimos variam conforme sentimos tristeza ou alegria, amor ou ódio. (...) persuadimos, enfim, pelo discurso, quando mostramos a verdade ou o que parece verdade, a partir do que é persuasivo em cada caso particular (...).

Nesse modelo, a instrumentalização de sentimentos e emoções das pessoas receptoras de um discurso parece contrariar a proposta de gerar convencimento, isto é, o "reconhecimento racional da necessidade de concatenações materiais". Entretanto, os fins e limites do emprego da retórica eram sempre norteados pela prudência, vinculada à razão. Ao contrário da dialética, idealizada por Platão, que buscava chegar a essências e "fins

retórico, além das características do dialético, refere-se a uma das três divisões da retórica: deliberativa (política), forense (judicial) ou epidítica (cerimonial, de louvor); cf. ADEODATO, 2011, p. 309.

${ }^{9}$ Contudo, reconhecer essas características retóricas do processo interpretativo/aplicativo do Direito não diminui a utilidade dos elementos metódicos tradicionais, uma vez que estes representam "trilhas de guias" experimentados e bem-sucedidos na produção da decisão jurídica durante séculos (cf. KRELL, 2014). 
últimos", o objetivo da retórica (e dialética) de Aristóteles era apenas alcançar "sentenças prováveis": aquelas que parecem verdadeiras para todos ou para a maioria das pessoas, ou para os sábios (ou para todos, ou para a maioria deles), ou para os mais famosos e respeitados (SCHRECKENBERGER, 2000, p. 374ss.). Exemplo típico desse fenômeno é o habitual recorrer da jurisprudência à "doutrina dominante" para arrazoar decisões. A autoridade desses "endoxa jurídicos" está na presunção de que eles já foram bem pensados, comprovados e reconhecidos pelos experts da matéria, o que, por sua vez, "pressupõe justamente que se pode argumentar de maneira racional sobre a sua retidão" (KRIELE, 1976, p. 135s.).

Entretanto, os argumentos retóricos não eram tidos como menos valiosos do que os dialéticos ou lógicos, mas apenas diferentes: os principais são o exemplo, que corresponde à indução, e o próprio entimema, como contraparte da dedução no âmbito da lógica (SMITH, 2009). Nessa visão, a probabilidade representava uma forma pragmática da própria verdade, que surgia a partir do contexto concreto, especialmente nos campos da Política e do Direito, onde o referido entimema (a "conclusão retórica") era visto por Aristóteles como mais útil do que o silogismo, a "conclusão lógica" (SCHRECKENBERGER, 2000, p. 376).

Gadamer (1993, p. 235ss., 273ss., 296ss.) entende que a retórica divide com a hermenêutica o espaço dos argumentos convincentes, considerando esta como uma "construção paralela" daquela. A retórica não é apenas a arte de persuadir os outros por meio da fala emocional, mas representa o mais tradicional meio para defender uma pretensão de verdade baseada no provável (verossímil) e naquilo que é aceito pelo senso comum, contra uma pretensa certeza científica. Na sua origem clássica, a retórica, como teoria, dirigia-se justamente contra o "enfeitiçamento da consciência" por meio do poder da fala dos sofistas.

Partindo das origens gregas e romanas desses conceitos-chaves, Adeodato (1996, p. 203s.) esclarece que a retórica jurídica distingue-se da ciência (episteme), que visa a garantir ou, pelo menos, tornar previsíveis os seus resultados por meio de verificação ou amostragem, tendo o seu objeto na phrônesis ou prudentia (situada no âmbito da doxa). A retórica é baseada no pensamento opinativo a ser operado pelos atos de justificar e argumentar numa relação intersubjetiva. Enquanto a ciência é obrigada a provar os seus postulados em busca do conhecimento, a phrônesis, que caracteriza o Direito, deve fundamentá-los para obter reconhecimento e credibilidade. $^{10}$

Ballweg (1982, p. 38s.) observou que na área do Direito:

Há um interesse sobretudo retórico quando alguém se apresenta como teórico onde ele, na verdade, fala como doutrinador ou dogmático, com a intenção de reforçar os próprios argumentos mediante um empréstimo de autoridade, chamando-os de científicos, ainda que se trata de argumentos prudenciais e, assim, meramente opinativos.

Aqueles que agem assim usam esta "falsa rotulagem" para poder participar de discussões políticas na

\footnotetext{
${ }^{10}$ Aristóteles (2001, p. 115, n. 1139b) pressupunha cinco diferentes formas de julgamento humano capazes de levar à verdade: techne (conhecimento técnico), episteme (ciência), phrônesis (prudência, "saber do bom"), sophia (sabedoria) e noûs (espírito, intelecto); cf. HÖFFE, 2008, p. 182.
} 
posição de "cientista", aproveitando-se do imaginário leigo sobre as "afirmações científicas irrefutáveis" e usando a máscara do cientista para blindar a sua opinião jurídica, política ou moral contra questionamentos e contestações.

Apesar de que os princípios e métodos retóricos não estarem ligados à lógica clássica, eles não deixam de ser racionais, visto que exigem sempre uma condução disciplinada do raciocínio e ganham poder de convencimento através de seu uso inteligente por pessoas competentes. Afinal de contas, não é função dos procedimentos retóricos comprovar algo, mas criar condições sob as quais os juízos de valor se mostrem razoáveis para uma pessoa pensante (TAMMELO, 1971).

\section{O DESCRÉDITO DA RETÓRICA NA TEORIA DAS CIÊNCIAS DA MODERNIDADE E A SUA REABILITAÇÃO EM TEMPOS DAS TEORIAS DE ARGUMENTAÇÃO}

Já nos anos 50 do sec. XX, o jurista alemão T. Viehweg ${ }^{11}$ destacava a crescente importância da análise crítica do processo de escolha e utilização dos argumentos por parte do cientista, o que tornaria a teoria científicofilosófica, em boa parte, uma teoria da argumentação. Isso valeria especialmente para a ciência do Direito - tanto a prudência quanto a pesquisa jurídica -, onde o objeto de investigação é a "fala arrazoada", que consiste na formulação de afirmações que estão sujeitas a uma "obrigação de defesa" e somente podem persistir se conseguirem corresponder a este desafio. Por isso, a retórica seria a melhor forma de controle de argumentações jurídicas num Estado de Direito (VIEHWEG, 1995, p. 195, 222).

No entanto, a retórica, que teve os seus momentos mais fortes na Antiguidade, teve de recuar já no final desta época, em virtude do declínio das assembleias deliberantes, que perderam o poder político para os imperadores e a Igreja. Questionou-se cada vez mais se a verdade realmente resultava do diálogo, da discussão, do cotejo das opiniões, ganhando força a crença nos meios diretos e imediatos de atingi-la. Com isso, a retórica acabou sendo transformada de técnica de invenção e discussão em uma técnica de apresentação e persuasão, ligada apenas à forma, mas não ao conteúdo do discurso. A partir do século XVII, as novas teorias científicas baseadas em evidências, provas e experiências, além de um crescente monismo de valores, suprimiram a importância da retórica como técnica argumentativa (PERELMAN, 1999).

Assim, os procedimentos retóricos e dialéticos entraram em descrédito e pleno declínio a partir da ascensão das ciências naturais na modernidade, com as obras de Bacon, Descartes e Locke, que exigiam o emprego de métodos estritamente racionais, lógicos e empíricos, na base de uma sistemática dedutiva e axiomática. Quando as ciências exatas chegaram a ganhar uma "superioridade hegemônica" e a encarnar a certeza do conhecimento, houve um abandono da própria razão prática: problemas do agir não reconduzíveis à verdade e ao saber objetivo passaram a ser vistos como alheios à própria razão (HORN, 2000, p. 408). A partir da época do

${ }^{11}$ Sobre a importância da obra deste autor para o Direito, inclusive o brasileiro, vide ROESLER, 2004. vol.09, n. 01, Rio de Janeiro, 2016.pp. 244-271 
Renascimento houve uma virada da tradição retórica em direção à leitura de textos clássicos, o que chamou ao plano a arte da interpretação: o compreender da hermenêutica, o "poder entender", passa a corresponder à tradição clássica da retórica, o "poder falar" (GADAMER, 1993, p. 280).

Na sombra do brilho das ciências naturais, a retórica foi reduzida a um tipo de "técnica de conversação" pouco útil. Somente a partir do meio do século XX, a mencionada redescoberta da retórica antiga e a guinada acadêmica para a pragmática da linguagem e a argumentação prática levaram a sua reabilitação. Além disso, novas descobertas científicas - especialmente na área da física (Einstein, Planck, Heisenberg) - causaram sérias dúvidas sobre a capacidade humana de obter conhecimentos suficientes sobre os processos da natureza e as suas complexas regras, reduzindo antigas "certezas absolutas" a meras probabilidades e afirmativas contingenciais. Assim, as formas de acesso a conhecimentos sobre a natureza e sobre a vida social se assemelharam, consistindo, basicamente, numa "luta permanente pela solução adequada de problemas", sem o recurso a "visões de mundo" holísticas (SCHRECKENBERGER, 2000, p. 377ss.).

Nos tempos atuais, Schreckenberger (2000, p. 367ss., 394) considera a retórica uma "teoria do falar arrazoado" cujo campo de ação é o opinar - nos últimos séculos, sempre visto em oposição ao saber - e exige o emprego de uma retórica culta, que constrói “conexões de justificação lastreadas em inferências compreensíveis". Para ele, especialmente os valores positivados nas normas constitucionais principiológicas possuem a "função retórica elementar" de expressar uma "doutrina básica" da sociedade, a ser transmitida através de textos, decisões e interpretações, a qual, no caso ideal, também reflete convicções sociais comuns. Esses princípios formam "campos destacados de argumentação tópica", a ser efetuada não por deduções, mas através de "procedimentos abstratos de rotulação semântica", característicos para toda argumentação de princípios. Para o autor, "as festejadas teorias do discurso da área jurídica, muitas vezes, ainda escondem as suas raízes retóricas”. Além disso, a retórica voltou a ocupar uma função fundamental em virtude da crescente influência da mídia de massa na sociedade, "interpenetrando-se de forma perfeita os aspectos retórico e hermenêutico do viés linguístico da vida humana" (GADAMER, 1993, p. 238).

Ainda que a retórica não alcance o grau de certeza exigido no âmbito das ciências naturais, ela representa um procedimento de conhecimento científico capaz de fundamentar racionalmente suposições e de dotá-las de validade intersubjetiva. É, portanto, equivocada a ideia da impossibilidade de conhecimento que não seja dedutivo ou resultado de experimentação e que, além dessas fronteiras, já começaria o campo das opiniões subjetivas; no meio desses dois polos, existe o vasto espaço dos conhecimentos baseados em argumentos justificadores (COING, 1993, p. 101s.).

A clássica determinação situacional da retórica aponta para a relação entre o orador, o discurso e o auditório. Toda criação jurídica termina em algo falado ou escrito, chamado na terminologia da retórica de 
discurso, que nunca é um "fim em si", mas deve causar algum efeito como entusiasmar, entristecer, fazer refletir, informar, aconselhar e, muitas vezes, influenciar a formação, confirmação ou mudança de uma opinião. Para não se perder no meio dessas várias "dimensões de efeito", a retórica restringe-se na sua análise à fórmula de que o orador quer convencer. A retórica faz mesma redução em relação aos outros dois conceitos básicos: a grande maioria dos oradores, na prática, não fala; e a maior parte dos auditórios não existe no sentido de ouvintes reais. Ambos os conceitos marcam na análise retórica apenas "os pontos desconhecidos de fonte e do escape das conexões de efeitos que realmente interessam, a saber: como um orador deve-se comportar para convencer um auditório" (SCHLIEFFEN, 2001, p. 179).

\section{RETÓRICA, ARGUMENTAÇÃO E INTERPRETAÇÃO JURÍDICA}

De forma semelhante, Aarnio (1979b, p. 21ss.) entende que o alcance da coerência de uma justificativa, que permite encerrar o aporte de novos argumentos, depende do relacionamento entre o intérprete do Direito e o destinatário de seu labor, a chamada "comunidade de interpretação", que equivale à famosa figura do "auditório". Os argumentos utilizados num discurso jurídico devem ser aceitos por este auditório, que não designa um número concreto de indivíduos presentes num local, mas representa certo grupo potencial de receptores, de quantidade não precisa, ao qual é direcionado o "esforço de persuasão". Assim, "a aceitabilidade alcançável por meio de argumentação pressupõe conceitualmente qualquer ambiente de discussão, qualquer auditório" (AARNIO, 1979a, p. 114).

A Nova Retórica de Perelman, concebida para a área do Direito, possui natureza eminentemente pragmática e busca alcançar a "razão prática" através da produção de soluções aceitáveis, que correspondem às ideias de justiça e razoabilidade prevalecentes em determinado meio. Segundo ela, a argumentação em favor de uma tese pode levar a sua aceitação não apenas por ela ser considerada "verdadeira" pelos participantes do discurso, mas por parecer, por exemplo, mais oportuna, útil, razoável ou mais adaptada à situação concreta. Argumentos retóricos não estabelecem verdades evidentes, mas mostram o caráter plausível e razoável de determinada decisão ou opinião. Partindo do pensamento aristotélico, o autor belga destaca que a lógica formal baseada no raciocínio analítico - tem por fim principal produzir conclusões que correspondem às premissas, enquanto o raciocínio dialético da lógica jurídica pretende "demonstrar a aceitabilidade das premissas", sempre à procura de uma solução que concilie os valores de equidade e segurança (ATIENZA, 2002, p. 84, 105, 109).

Enquanto o discurso filosófico se dirige a um auditório universal, nas áreas do Direito, da Política e da Moral os auditórios são particulares, sendo a decisão sempre condicionada socialmente, vinculada à ordem jurídica e subordinada à razão resultante do desenvolvimento histórico, das tradições e da cultura de determinada comunidade (PAVČNIK, 1993, p. 139). O processo da criação jurídica possui a especificidade de que o orador 
deve, no final de sua exposição, apresentar um resultado e declará-lo como "o correto", "o certo", pondo um fim à insegurança. Essa "coerção à decisão" (Entscheidungszwang) distingue o Direito do pensamento filosófico e das ciências naturais, destacando que ele "não visa a alcançar o saber ou a sabedoria, mas representa um agir prático e voltado para produzir efeitos" (LAUNHARDT, 2005, p. 4).

No entanto, a retórica jurídica, embora seja bastante adequada para integrar os diferentes modelos empíricos e de análise linguística, ainda não se livrou da suspeita de abandonar de forma leviana os consagrados (e, de certa forma, imutáveis) postulados da vinculação legal e do controle racional da decisão jurídica. Ela, na verdade, não nega os referidos postulados, mas pretende chegar a uma avaliação mais realista das possibilidades de nortear processos de decisão jurídicos e a uma autoimagem mais refletida dos aplicadores do Direito (SCHLIEFFEN, 2001).

Assim, é o mérito da retórica ter provocado uma gradual mudança na ciência jurídica, que se afastou cada vez mais da ideia da decisão como pura dedução mecânica da lei e atribuiu importância central aos argumentos decisivos. A própria retórica jurídica pode ser definida como “técnica para criar consentimento", não havendo uma nítida linha divisória entre ela e a argumentação jurídica (KREUZBAUER, 2004, p. 12, 19s.). Enquanto a retórica se define como disciplina que trata da descoberta de estruturas típicas da argumentação jurídica, a teoria normativa da argumentação está preocupada com as regras de um correto (= o melhor) arrazoamento (NEUMANN, 2001).

Como a retórica sempre tem se preocupado com a argumentação e o convencimento, ela também ganha importância para o intérprete jurídico, visto que o processo de produção da sua decisão está ligado à aprendizagem, reflexão, argumentação, discussão e ao consenso. Haft (1984, p. 95) enfatiza que a retórica não serve apenas para melhorar o desempenho técnico do operador do Direito (ex.: a defesa do advogado penalista perante o tribunal de júri), mas atinge o centro de toda atividade jurídica: a geração da correspondência entre ser e dever-ser, isto é, entre suporte fático e norma. Assim, uma decisão sempre deve ser preparada reflexivamente mediante a elucidação do horizonte de pré-compreensão e testada argumentativamente nos seus pontos favoráveis e contrários a uma posição. Onde não houver esta ponderação, para ele, a decisão não será capaz de gerar consenso; ainda que ela transite em julgado, "ela não pode ser correta, em virtude da insuficiência de sua retórica”.

No entanto, a retórica passa dos seus limites quando leva a crer que o discurso jurídico deveria ser avaliado exclusivamente na base de seu sucesso. Este discurso pretende ter uma força de convencimento objetiva, isto é, independente das preferências individuais, interesses e posições ideológicas dos endereçados. A argumentação jurídica não se dirige a um público concreto (partes, advogados, promotores, juízes), mas ao auditório universal de Direito, que somente pode ser convencido por meio de argumentos jurídicos racionais. Isto 
porque "imparcialidade e objetividade não são apenas virtudes do juiz, mas representam a própria »arte retórica« dos juristas" (NEUMANN, 2008, p. 80ss.). ${ }^{12}$

Para Castro Júnior, o teor ontológico do raciocínio jurídico "não mais precisa ser visto com tanta desconfiança quando nos libertamos de uma (também ingênua) pretensão de que tenha grande significação científica" (CASTRO JR, 2009, p. 136). Na sua tarefa de guiar o pensamento no âmbito do Direito, a retórica não pretende ser bem-sucedida ou eficaz a qualquer preço, mas tem por fim convencer os destinatários dos argumentos usados, para que eles realmente reconheçam a sua retidão e concordem em virtude da razoabilidade do discurso (TAMMELO, 1971).

Krawietz (1979, p. 124, 147s.) adverte que uma análise das conexões internas da argumentação jurídica deve respeitar a relação complementar entre lógica, tópica e retórica, que encontra a sua expressão linguística na argumentação, justificação e decisão, criando uma ligação entre e a vivência fática do sentido normativo e sua articulação nos textos legais, com o fim de melhor definir a prática jurídica convencional de pensar, arrazoar e decidir. Enquanto o objetivo da tópica é fornecer pontos de orientação fortes no senso comum ou em opiniões respeitadas que garantem aceitabilidade prática, a retórica pretende assegurar que os argumentos apresentados para justificar decisões jurídicas possuam consistência e aceitabilidade prática. Limitar a metodologia do Direito à "captação estilisticamente correta" do sentido de textos legais significaria, para o autor, reduzir o trabalho complexo da argumentação, justificação e decisão jurídica a um aspecto meramente parcial.

O autor ressalta também que a tradicional lógica da dogmática jurídica nunca tratou apenas de questões formais ou de estilo. Por isso, a orientação geral de analisar o Direito a partir de sua linguagem deveria ser baseada mais na dimensão pragmática (sociologicamente diferenciada) da justificação da fala jurídica, que em focalizar demasiadamente os aspectos sintáticos e semânticos, fixados na teoria do conhecimento (KRAWIETZ, 1979, p. 151s.). Na mesma direção vai a critica quanto à exigência de justificar as típicas operações jurídicas valorativas, necessariamente, na tradicional base cognitiva, em vez de aceitar uma justificativa relacionada à sua eficiência, isto é, à própria função do Direito de ordenar o comportamento humano (PECZENIK, 1979).

\section{A RETÓRICA COMO MEIO DE ANÁLISE CRÍTICA DO DISCURSO JUDICIAL}

Schlieffen (2005, p. 321) investigou profundamente o fenômeno da "produção de plausibilidade jurídica" na realidade forense da Alemanha, analisando um elevado número de sentenças judiciais, com foco no uso e efeito dos meios retóricos de logos, ethos e pathos. Sua pesquisa revelou que justamente nos pontos

\footnotetext{
${ }^{12}$ Assim, a argumentação de um advogado não pode ser expressamente baseada no seu (óbvio) interesse econômico em defender o seu cliente. "Para ganhar relevância jurídica, interesses devem ser convertidos à moeda comum de argumentos jurídicos. Ao mesmo tempo, transformam-se desta forma interesses divergentes e a princípio não compatíveis em problemas jurídicos solúveis" (NEUMANN, 2008, p. 83).
} 
sensíveis e decisivos do processo de produção da decisão jurídica predomina o uso de figuras retóricas, não de argumentos técnicos. Os entimemas costumam ocultar as premissas e conclusões intermediárias dos julgadores, o que dificulta sobremaneira a reconstrução do raciocínio judicial. Não prevalece uma cadeia dedutiva completa baseada em normas, mas a sequência de sustentações concentradas em problemas mediante endoxa; estes, muitas vezes, são meramente aparentes e levam a conclusões erísticas; no entanto, fazem a ponte entre os mundos normativo e fático. Essa forma de produção da decisão contradiz as metodologias tradicionais e a própria autoimagem jurídica, marcada pelos conceitos da verdade, objetividade e clareza, e aponta para matizes retóricos de interpretação e aplicação do Direito.

O estudo da retórica na área do Direito pode ganhar importância especial no Brasil, onde prevalece um tipo de racionalidade na produção das decisões jurídicas que não pode ser facilmente enquadrado em padrões alienígenas.

Rodriguez (2013, p. 62s., 77ss., 101ss, 107s.), a partir de uma pesquisa empírica, alega que a jurisdição brasileira funciona, sobretudo nos casos controversos, na base da invocação de autoridade (s), na forma da agregação de opiniões individuais. A justificação da decisão reproduz apenas as razões pelas quais aquele que a redigiu se convenceu de determinada solução, o que faz com que a legitimidade deste tipo de "justiça opinativa" não se fundamente numa argumentação racional unificada do órgão prolator da decisão. Para o autor, a função primordial do juiz no Brasil é formular opiniões fundamentadas perante casos concretos de forma pública, aberta, "às vezes diante de uma plateia, e não encontrar a melhor resposta para eles a partir de um raciocínio sistemático". Por isso, a sentença publicada seria apenas registro cronológico dos debates ocorridos e não um texto coerente que articula argumentos dogmáticos. ${ }^{13}$

Esta formação institucional afastaria a utilidade das tão festejadas teorias de argumentação, fazendo com que os modelos de racionalidade jurídica presentes nas obras de autores como Dworkin, Alexy e Habermas, apesar de bastante citados pelos tribunais, não exerceriam uma efetiva influência sobre o modo de raciocinar dos operadores do Direito brasileiro. E, ainda que o modelo ocidental de Estado de Direito exija uma fundamentação jurisdicional norteada por argumentos racionais, baseada no logos, não seria este o padrão de legitimação que bem funciona na prática institucional brasileira, prevalecendo o discurso jurídico lastreado no ethos e no pathos. Por isso, para obter "um quadro mais fiel do que ocorre em nosso país", o autor entende adequado o uso da retórica como modelo descritivo para a racionalidade jurisdicional, a exemplo da obra de Tércio Sampaio Ferraz Júnior (RODRIGUEZ, 2013, p. 15, 68, 77, 103s.).

É óbvio que neste ambiente de decisões forenses pouco padronizadas e previsíveis, a análise retórica do

\footnotetext{
${ }^{13}$ Em geral, as ementas das decisões dos tribunais brasileiros não costumam fornecer um resumo dos argumentos utilizados nos votos dos ministros ou desembargadores. Há inúmeras sentenças baseadas em votos individuais materialmente díspares e até contraditórios, a exemplo da decisão do STJ (REsp 598.281 MG, Rel. Min. L. Fux), de 2006, que versa sobre a admissibilidade do dano moral ambiental coletivo (RODRIGUEZ, 2013, p. 98ss.).
} 
discurso jurídico assume especial relevância para uma melhor compreensão do comportamento dos agentes e dos problemas em geral.

\section{AS ORIGENS DA TÓPICA COMO INSTRUMENTO DA RETÓRICA}

As disciplinas da retórica e da tópica possuem vínculos estreitos: enquanto a tarefa da primeira é determinar, elucidar e apresentar sistematicamente certos procedimentos de argumentação capazes de assegurar a retidão do conteúdo dos pensamentos neles utilizados, a segunda tem por fim a análise das típicas figuras de raciocínio utilizadas nesses processos. Assim, o "método tópico" de interpretação assenta nas antigas práticas da tópica e da retórica, que são transferidas para a ciência do Direito a fim de servir como doutrinas de argumentação e fundamentação (WOLFF et al., 2006, p. 415). A tópica possui o caráter de uma retórica que pretende superar conflitos sociais por meio da linguagem, ordenando, sopesando, avaliando e ponderando todos os argumentos relevantes para viabilizar uma decisão adequada (MASTRONARDI, 2001).

Na sua obra Tópica (capítulos II-VII), Aristóteles criou uma compilação de regras argumentativas chamados de topoi (= lugares). Com este catálogo, ele não pretendia classificar sistematicamente todos os argumentos válidos e corretos conhecidos na época, mas apenas fornecer uma lista de dispositivos que servia para descobrir determinadas formas de premissas, das quais, por sua vez, podiam ser deduzidas certas conclusões. ${ }^{14} \mathrm{O}$ filósofo aplicava a tópica "a argumentos que não se apoiam em premissas seguramente verdadeiras, mas antes em premissas simplesmente plausíveis"; ela era, portanto, diretamente ligada à dialética aristotélica, que se distinguia bastante daquela idealizada por seu mestre Platão (SMITH, 2009).

A tópica clássica pertence à "arte de achar argumentos" no momento certo e, por isso, ganhava especial importância nas lides judiciais, o que levou à formulação de uma específica "tópica forense" no Império Romano. O jurista Marcus Quintilianus (35-95 p. C.) distinguia entre os topoi ligados à pessoa (loci a persona), como nacionalidade, idade, sexo, educação, tipo corporal, patrimônio etc., e os relacionados à própria coisa (loci a re): causa, lugar, tempo, modo, fim, comparação, circunstância, entre outros (p. 143s.).

No entanto, não se deve olvidar que a antiga tópica tratava, sobretudo, da definição de "coisas reais" e servia para acrescentar argumentos aos discursos da vida intelectual em geral. Ao contrário, no mundo jurídico moderno, a necessidade de definir ou de argumentar sobre algo está orientada, sobretudo, pelo próprio Direito positivado. Aqui, a ênfase está nas consequências que a aplicação da norma poderá provocar, o que faz com que as definições jurídicas sejam formuladas com vista aos fins e resultados, de modo bem diferente do procedimento

\footnotetext{
${ }^{14}$ Smith (2009, p. 97s.) explica como lidar com os topoi no estilo aristotélico: "Para encontrar meu argumento, eu primeiramente procuro uma localidade apropriada a minha conclusão desejada e a uso para descobrir premissas que seriam úteis; em seguida, consulto o inventário de opiniões relevante para ver se aquelas premissas são encontradas ali. Se elas são, tenho meu argumento; tudo o que resta é formulá-lo na forma de questões e apresentá-las ao meu oponente." Nessa escolha dos topoi adequados, deve ser avaliado também o "tipo de pessoa" do respectivo oponente.
} 
tópico clássico (KRIELE, 1976).

Também não se pode esperar do conceito da tópica um sentido uniforme e preciso, visto que ele, durante os séculos, sofreu diversas alterações por ter sido envolvido em várias polêmicas entre teorias filosóficas. Dependendo da época histórica e do contexto material, a tópica associou-se tanto à retórica quanto à dialética (clássica).Junto com estas, ela caiu, igualmente à retórica, durante vários séculos em descrédito intelectual, sendo "redescoberta" para a área do Direito somente em meados do século XX. Kant (1787, p. 379) ainda considerava a tópica aristotélica um método "de que professores de ginásio e oradores podiam se servir para (...) formar, sob a aparência da profundidade, juízos pretensamente racionais ou tagarelar verbosamente".

\section{A REDESCOBERTA DA TÓPICA PARA A ÁREA DO DIREITO}

Em 1953, T. Viehweg publicou a obra Tópica e jurisprudência, ${ }^{15}$ na qual apresenta a tópica como um método para combater uma argumentação jurídica excessivamente formal ou arbitrária. Ele identifica o raciocínio tópico com o aporético e o contrapõe ao pensamento sistêmico, que trabalha com a dedução de um sistema jurídico axiomático, construído de forma piramidal (KRIELE, 1976). Para o jurista alemão, a solução dos problemas postos pelos casos jurídicos costuma ser alcançada por meio de "pontos de vista" (topoi) que possuem poder de convencimento e reconhecimento geral, como as "verdades comuns convencionais", regras e máximas da razão prática, provérbios ou frases de sabedoria popular; na área do Direito, ainda há os padrões existentes na sociedade, além dos precedentes reconhecidos e das proposições doutrinárias.

Já na teoria original de Aristóteles, os topoi não serviam para produzir juízos apodíticos, senão para convencer a maioria (ou "os melhores") ou sustentar "a arte da persuasão retórica", o que mostra que a tópica sempre esteve orientada para fins práticos. No processo de raciocínio jurídico, eles funcionam como "argumentos de discussão que devem fundamentar um convencimento geral a respeito da retidão da solução achada na discussão" (WIEACKER, 1970, p. 327).

Viehweg descreve a tópica ${ }^{16}$ como uma techne de raciocínio cuja função principal é introduzir na discussão jurídica novos aspectos materiais ligados a determinado problema (ars inveniendi). Ela serve para identificar argumentos ligados a um problema através da confrontação do suporte fático com pontos de vista que já são legitimados pela aceitação das partes da disputa; ${ }^{17}$ a partir destes, são produzidas premissas para a solução

\footnotetext{
${ }^{15}$ Seja frisado que Jurisprudenz, em alemão, significa, neste contexto, "ciência do Direito".

${ }^{16}$ Nas obras de Viehweg e de seus seguidores, o termo tópica pode ser entendido como:

1. Uma técnica para buscar premissas;

2. Uma teoria sobre a natureza das premissas;

3. Uma teoria sobre o uso dessas premissas na fundamentação jurídica (ATIENZA, 2002, p. 70).

${ }^{17}$ Os topoi "primários" contemplam a coisa como um todo ou se referem a determinadas relações do problema, como categoria, espécie, semelhança, diferença, pontos contrários, fatores acidentais, causas, efeitos, comparação (VIEHWEG, 1969, p. 14).
} vol.09, n. 01, Rio de Janeiro, 2016.pp. 244-271 
do caso. Assim, pode-se dizer que a tópica não representa, propriamente, um método, mas um "estilo de pensar"; ela não forma um conjunto de princípios para fins de avaliação e tampouco de cânones para testar a adequação das propostas, nem fornece critérios a fim de escolher hipóteses. Os topoi apenas "constituem pontos de partida para séries argumentativas, em que a razoabilidade das opiniões é fortalecida” (FERRAZ JR., 1994, p. 327s.). É questionável, portanto, se existe realmente um "método tópico de interpretação constitucional” (SENA JR, 2008, p. 217); parece ser mais adequado falar de um "estilo tópico" de interpretar as leis constitucionais.

Segundo Castro Júnior (2009, p. 48ss.), a retomada da tópica, "desde a antiga disciplina que servia à dialética como ainda serve à retórica, traz-nos ao domínio da linguagem como »ação «", devolvendo "à reflexão jurídica a dimensão pragmática, a preocupação com o efetivo uso da linguagem pelos aplicadores, e a tematização desse aspecto central da experiência jurídica”. Para ele, existem na visão tópica, em vez de um saber jurídico último, "vários esquemas sintático-semânticos parciais, mais ou menos úteis para a prática do discurso argumentativo, conforme a intenção de quem deles se valha, levando em consideração a suscetibilidade do auditório a que se dirige o argumento".

A interpretação no estilo tópico exige a identificação de topoi relevantes para a solução do problema em análise; estes são enfrentados com o caso concreto para, por fim, sofrer uma "ponderação recíproca" (ACHTERBERG, 1979, p. 46). Verdadeiros topoi são aceitáveis de forma generalizada por não expressarem interesses grupais, que seriam imediatamente identificados com as posições concorrentes dos diferentes atores sociais; assim, o emprego de topoi adequados aumenta a probabilidade de se chegar a uma decisão correta (STRUCK, 1977). Tópico, portanto, pode ser considerado um argumento "tirado da gaveta", aquele que já possui o seu "lugar"; trata-se, no fundo, de atualizar reflexões já realizadas para o problema em questão. O pensamento tópico, que procura premissas, contudo, não se limita a reproduzir conhecimentos já disponíveis, mas envolve também o emprego produtivo desse tipo de raciocínio (ZIPPELIUS, 1996, p. 407ss.).

Os topoi são ordenados, segundo interligações objetivas, em direção a determinados problemas, marcando pontos fixos de orientação no âmbito de uma questão polêmica. Ainda que impeçam que a solução de um caso seja aleatória, eles não determinam um conteúdo fixo para a decisão, deixando espaços para uma "ponderação móvel dos possíveis resultados" (HENKEL, 1964, p. 418). Estes "lugares-comuns" de uma argumentação têm uma função semelhante à dos axiomas num sistema formal: "podem servir de ponto inicial justamente porque os supomos comuns a todos os espíritos". Entretanto, a concordância sobre eles "não garante o acordo sobre sua aplicação concreta e, portanto, sobre as conclusões a que chegaremos" (PERELMAN, 2004, p. 159s.).

Além do mais, muitos dos aspectos argumentativos que se tornam lugares-comuns logo "escapam da reflexão intelectual", não sendo incomum que um auditório tire conclusões decisivas de fatos objetivamente 
banais ou até irrisórios. As premissas estabelecidas por certos topoi podem ser inverídicas, inexpressivas ou até absurdas, e ainda assim cumprir a sua função de tornar aceitáveis determinados juízos de valor utilizados num discurso (BALLWEG, 1982, p. 36). Destarte, os lugares-comuns tópicos "pressupõem um acordo o qual, se for discutido em detalhes, tende a se enfraquecer e daí a desaparecer", porque "sua força vinculante reside exatamente no caráter não explícito" (ADEODATO, 2011,p. 208).

Os topoi são assim opiniões genericamente disseminadas, em geral sobre pretensas causalidades - que apelam a efeitos necessários ou a posicionamentos éticos que se pretendem verdadeiros e, como tais, acima de quaisquer argumentos -, embora o retórico saiba que essa pretensa causalidade não é pertinente. Assim, apresentam-se como causais: (...) “O mau ambiente produz tendência ao crime' (essa pessoa provém de um mau ambiente; logo tende ao crime).” (ADEODATO, 2011, p. 310 - grifos no original.)

A falta de precisão linguística na formulação de muitos topoi é compensada pela consideração de sua utilização habitual ou específica em certas situações; basta que o grupo dos endereçados assimile de maneira intuitiva os pontos argumentativos que eles expressam. Isso significa também que a argumentação a partir de topoi exige certas qualidades mentais dos participantes, como tato, moderação, atenção, probidade e a disposição de repensar as próprias convicções (TAMMELO, 1971).

Wieacker atribui a ressurreição da tópica à da própria retórica, causada pelas crises da lógica clássica e do formalismo científico. Para ele, o domínio legítimo da tópica é não apenas a identificação e a seleção de argumentos relevantes para uma decisão, mas também a chance de chegar a "regras comportamentais socialmente vinculantes da moral prática", longe do formalismo dogmático ou do objetivismo axiológico metafísico. No entanto, o autor questiona a função especificamente retórica da tópica, visto que nas sociedades modernas a comunicação imediata pelo "argumento retórico vitorioso" teria perdido importância na formação das regras de comportamento que ainda possuía na democracia direta da polis grega. A mídia moderna utilizaria a palavra apenas como "estímulo unilateral", despojando-a de sua função intercomunicativa. Mesmo assim, Wieacker (1979, p. 328s.) reconhece a função da tópica como arte do "agir prático correto", mormente na troca de argumentos para fins da aproximação comum a uma "verdade prática" na aplicação do Direito, através de petições judiciais, conversas nas câmaras dos tribunais, discussões doutrinárias etc.

\section{AS VISÕES TÓPICA E SISTEMÁTICA DO DIREITO: CONTRADIÇÃO OU COMPLEMENTAÇÃO?}

A ideia de um sistema coeso do Direito tenta dotar o pensamento jurídico de racionalidade, gerando uma relação consistente entre a decisão e a ordem jurídica. A palavra sistema assinala apenas um "efetivo de normas e princípios gerais que formam uma ordem de comportamento capaz de funcionar, que não se 
contradizem logicamente e cujos fins são compatíveis entre si” (ZIPPELIUS, 1996, p. 36.). Max Weber (1980, p. 396) entendia a sistematização do Direito como o estabelecimento de uma relação de todas as regras jurídicas analiticamente descobertas de um modo que elas formassem entre si um sistema logicamente claro, livre de contradições e, a princípio, sem lacunas. No século XX houve, contudo, um enfraquecimento do conceito estrito de sistema, que cedeu um espaço crescente à ideia de um "sistema aberto", inclusive na área do Direito (PFORDTEN, 1993, p. 410, 423).

Assim como nas demais áreas da ciência, o Direito pode ser entendido como construção conceitual na base de pressupostos acerca de um setor autônomo da realidade. Mediante conceitos coordenados forma-se uma "totalidade coerente", um sistema que tenha certa unidade, afastando-se as contradições internas. Assim, "o rigor científico de um conjunto de conhecimento" depende decisivamente do nível de sua sistematização (VILANOVA, 2003, p. 4, 24).

Para Canaris (1983, p. 16ss.), a alegação de uma ordem e/ou de um sistema do Direito, com o fim de garantir a sua unidade e coerência, é comprovada já pelo próprio postulado básico de justiça: tanto o legislador quanto o juiz devem, em respeito ao princípio da igualdade, retomar as valorações já adotadas antes e "pensá-las até o fim”, na base de um raciocínio consequente. Romper com a linha material de juízos valorativos formulados em determinado ramo do Direito só se justifica por motivos objetivos.

Kriele (1976, p. 114ss., 121) põe a afirmativa de que "raciocínio jurídico é tópico" (Viehweg) em contraste com a alegação de que "a ciência do Direito é sistemática ou ela não existe" (H. J. Wolff). Ele entende a primeira frase como um "apelo para que não se pressuponha nem se aspire ao sistema jurídico, mas de deixar a técnica jurídica da práxis do jeito como está e de entendê-la como procura contínua »pelo respectivo justo «". Destarte, "sistemas sempre são apenas tentativas, esboços que possuem validade provisória", sujeitos à correição; ainda assim, seria correto falar de um sistema, já que as diferentes normas da ordem jurídica estão interligadas pelos mesmos conceitos, motivos, condições etc.

Por isso, o "pensar sistemático" do Direito não seria incompatível com o raciocínio tópico, visto que os próprios sistemas costumam nascer de catálogos de topoi, que são "as primeiras tentativas de organizar uma matéria caótica e torná-la compreensível". A reivindicação da tópica de que o sistema jurídico fique aberto a novos argumentos não se opõe ao sistema dogmático em si, mas à ideia errônea de que este seria completo e definitivo. Todavia, é decisiva a questão "de onde podem ser extraídos os aspectos para a correição, extensão e modificação" desse sistema (KRIELE, 1976, p. 145, 149ss.).

$\mathrm{Na}$ verdade, a conexão entre o problema concreto e os argumentos que levam à formulação das respectivas premissas é apenas presumida, não havendo uma demonstração de que elas podem ser enquadradas num sistema maior. Este fato parece contrariar a tarefa essencial do Direito de gerar e manter uma estrutura firme 
e coerente de comportamentos devidos. Todavia, o raciocínio problemático da tópica não se contrapõe ao pensamento sistêmico de um ordenamento jurídico, que pode ser visto como um "contexto de dedução", no qual os problemas são enquadrados para achar soluções coerentes. Antes, porém, que se possa deduzir algo que abra o caminho para conclusões (mais ou menos) evidentes, é preciso apresentar premissas tematicamente adequadas. Por isso, "o raciocínio interpretativo deve se mover no estilo da tópica" (VIEHWEG, 1969, p. 17ss., 33ss., 47, 61ss.).

Assim, há uma relação complementar entre a interpretação orientada por problemas e aquela baseada na dedução de conceitos. Até Canaris (1983, p. 144, 149s., 154, 160), para quem a tópica "não acerta, em princípio, a essência da ciência do Direito", admite que ela possui a importante função de ajudar na solução de casos para os quais a legislação positivada não fornece valorações suficientemente concretas, deixando o raciocínio sistemático chegar a seus limites. Nessa hipótese, ele aceita que o juiz efetue uma valoração própria, estritamente orientada nas "valorações e convicções jurídicas, culturais e sociais prevalecentes na respectiva comunidade de Direito", como no caso do preenchimento das cláusulas gerais do Direito Civil e dos conceitos vagos da Constituição.

No entanto, assiste razão a F. Müller (2008, p. 68ss., 79ss.) quando afirma que num Estado do Direito a preferência deve ser da norma posta pelo legislador. Também no âmbito da Constituição, o nexo normativo menos concreto e denso não faz com que "o primado metodológico deveria migrar da norma para o problema"; ao contrário, é necessária uma legitimação da "relevância dos pontos de vista do problema (...) diante da imagem normativa de ação da prescrição a ser concretizada". Para o autor, na área do Direito Constitucional, o "estoque de topoi é muito menos confiável" do que no âmbito do Direito Civil, além de que "as pretensões de normatividade são mais fundamentais".

Autores adeptos à tópica exigem que o pensamento jurídico moderno seja menos "sistêmico" e fixado em axiomas, e mais concentrado na solução dos problemas mediante a subdivisão dos fatos de acordo com os seus itens polêmicos. Depois, é preciso analisar tais por diversos pontos de vista: estruturas sociais e de interesses, a ordem dos bens jurídicos, figuras lógico-objetivas como a natureza das coisas, proporcionalidade, adequação dos meios, efetividade em relação aos fins, o desenvolvimento jurídico paralelo em diferentes países, ideias valorativas do Direito como os direitos fundamentais, proteção da confiança, equidade, princípio da justeza etc., para, depois, tentar achar um resultado correto. Esse tipo de raciocínio dialético, contudo, teria de ser "axiologicamente permeado", enquadrando-se o âmbito da norma num "contexto maior de sentido", identificando-se as respectivas valorações bem como medindo e "orientando-as à ordem constitucional de valores para evitar valorações subjetivas não controladas" (STEIN, 1966, p. 70).

$\mathrm{Na}$ verdade, a argumentação sistemática e a argumentação tópica devem se complementar reciprocamente: na primeira etapa da análise interpretativa, o sistema jurídico forma o quadro para a percepção do 
problema, seguida pela pergunta referente aos princípios subjacentes que normalmente fornecem os aspectos decisivos para a valoração a ser efetuada em busca da solução do caso. Destarte, o sistema somente pode ser entendido à luz do problema (MASTRONARDI, 2001).

\section{A TÓPICA COMO TÉCNICA DE RACIONALIZAÇÃO DAS INTERPRETAÇÕES NA ÁREA DO DIREITO}

Não há dúvida de que o raciocínio dedutivo, que prevalece até hoje nos tribunais dos países do civil law, busca dar solução adequada às lides; entretanto, ele "pretende cortar as questões econômicas, históricas, sociológicas e as (decisivas) valorativas", por serem assuntos pretensamente políticos e, por isso, de competência exclusiva do legislador, restringindo-se à análise das valorações deste ou da lei. Portanto, a referida afirmação de Viehweg de que o raciocínio jurídico seria necessariamente tópico revela também "que problemas jurídicos devem ser vistos em toda sua complexidade" (KRIELE, 1976, p. 123).

Ainda que a tópica seja adequada para identificar relevantes pontos de vista jurídicos, ela não resolve a questão central da avaliação concreta das diferentes sugestões trazidas para a solução do problema o seu respectivo peso na decisão. Ela não cria "regras de preferência" na necessária ponderação entre os argumentos derivados dos topoi, salvo se aquelas já se acham incluídas nestes (o que é a exceção), e precisa ser complementada por um "sistema de valores", que foi estabelecido no catálogo dos direitos fundamentais nas constituições de vários países. É essencial, porém, a pergunta: até que ponto o resultado de uma interpretação efetuada por meio do raciocínio tópico se deixa compreender também "de maneira metódico-racional"? (ENGISCH, 1983, p. 384s.)

A tópica põe a dogmática jurídica mais perto das exigências da prática, libertando-a da falta de categorias conceituais adequadas para os casos concretos. Neste ponto, os topoi possuem uma função dupla: são ideias diretoras que permitem travar uma discussão mais precisa sobre um problema; além disso, são vocábulos que designam um campo de significados, o qual, embora diversificado, elimina certas possibilidades de interpretação. Assim, eles reúnem em si um componente heurístico ${ }^{18}$ e outro hermenêutico (STRUCK, 1971, p. 64ss., 78).

O pensamento jurídico tópico também superou a teoria realista, para a qual quase somente as emoções (irracionais) do sujeito julgador determinam o resultado, visto que ele propõe analisar os modos de argumentação e, assim, ressalta a importância da comunicação intersubjetiva no processo decisório. Mesmo assim, questiona-se até hoje a razão da obrigatoriedade dos argumentos fornecidos pela tópica. Atrás da autorização do operador jurídico para formar o seu juízo de maneira tópica podem se esconder reservas latentes de autoridade e tradição,

\footnotetext{
${ }^{18}$ A heurística trabalha com conceitos e procedimentos de investigação que, apesar de serem conjecturais e provisórios, "fornecem conhecimentos adequados ainda que sem fundamentação rigorosa ou pretensão de verdade definitiva” (ADEODATO, 1996, p. 199).
} 
incompatíveis com o controle público e a transparência da aplicação do Direito nas modernas sociedades democráticas (WIEACKER, 1970, p. 331s.).

O emprego dos elementos metódicos clássicos do Direito também pode ser beneficiado pela tópica. $\mathrm{Na}$ verdade, os cânones de interpretação jurídica já encontram paralelos na tópica aristotélica: o topos da "redução de um conceito a seu conteúdo significativo original" é comparável ao elemento gramatical (literal); o da "ideia da coisa" parece com o método teleológico; e os topoi que enfatizam o respectivo contexto de pensamento e a correta atribuição e organização apresentam semelhanças com a interpretação sistemática. Assim, o instrumentário metódico tradicional do Direito, até certo ponto, constitui uma composição de topoi juridicamente reconhecidos e bem-sucedidos. O emprego de uma ou outra forma de inferência (ex:: analogia ou argumento a contrário) não segue regras lógicas, mas ocorre em virtude de ponderações valorativas. Por isso, os elementos metódicos ajudam na obtenção de soluções plausíveis para os problemas interpretativos, mas não conduzem a resultados unívocos e cogentes (LAUNHARDT, 2005, p. 46s.)

Para diminuir o âmbito do decisionismo na interpretação do Direito (no estilo de Kelsen e Hart), o uso de topoi cria elos com a experiência e a autoridade. Entretanto, estes dependem de certo consenso sobre o seu conteúdo; sua pré-compreensão sempre será guiada por verdades reconhecidas e autoevidências existentes na sociedade (STRUCK, 1971). Levantamento e troca de argumentos no "estilo tópico" para fins de aperfeiçoamento do Direito pressupõem um fundamento comum de discussão, formado por ideias culturais e atitudes valorativas semelhantes, certas opiniões predominantes, existência de um senso comum, uma reconhecida teoria material da Constituição etc. É de frisar, contudo, que são preponderantemente os países de tradição democrática constante que podem confiar (até certo ponto) no common sense de suas sociedades (KRIELE, 1976, p. 107, 151).

Além disso, deverá haver uma correição da argumentação tópica através do emprego do método dedutivo-sistemático: enquanto cabe àquele identificar o problema do caso concreto e sugerir pontos de vista para sua solução, baseados em máximas geralmente reconhecidas, incumbe a este controlar a coerência dessas propostas no contexto geral de princípios e regras da ordem jurídica. Cada um desses procedimentos exerce, em relação ao outro, tarefas seletivas e limitadoras, estabelecendo-se, assim, uma "interdependência prática" (WIEACKER,1970, p. 334s.).

Ballweg (1982, p. 45ss.) sublinha que conexões argumentativas mais extensas não se produzem, preponderantemente, por demonstrações lógicas, mas mediante "transições tópicas", como a troca da maneira de interpretar, explicações essencialistas de conceitos, afirmações ontológicas ou reificações gerais. Porém, os participantes de discursos normalmente consideram essas formas de interligação de argumentos somente familiares, plausíveis e coerentes quando aparecem como deduções lógicas, desprezando-se facilmente a sua 
natureza costumeira e habitual (entimemática). Para o autor, o objeto da análise teórica do Direito sempre será "o pensamento opinativo jurídico da iurisprudentia que, apesar da sua dogmatização, está exposto a vários perigos e tentações e que não consegue fornecer certeza definitiva”. Mesmo assim, este raciocínio prudencial do jurista deve fazer "sentir segurança no meio do inseguro", delimitando "o infinito situacional por redução verbal, garantir decidibilidade, oferecer sustento ativo no insustentável, proporcionar 'explicação' do inexplicável e reduzir o estranho ao já familiar".

Uma percepção moderna da tópica deixa claro que uma discussão pública coerente apenas é possível nos moldes de lugares-comuns geralmente aceitos ou potencialmente consensuais, isto é, "pontos de vista, princípios, regras metodológicas costumeiras ou ideias diretivas". Uma argumentação adequada e bem-sucedida exige a prévia identificação de pontos comuns nas opiniões, atitudes e expectativas sociais ou a tentativa de criá-las. Essas convicções comuns, muitas vezes denunciadas como pré-juízos, representam o horizonte compartilhado de comunicação e integração de uma sociedade e se manifestam - apesar de diferenças, conflitos ou manipulações pela mídia - em elementos iguais ou parecidos das pessoas na sua maneira de falar, sentir e agir (SCHRECKENBERGER, 2000, p. 389ss.).

Esser (1979, p. 26s.) mostrou que também faz parte do "tesouro" da tópica um leque de máximas jurídicas modernas, muitas vezes formuladas como princípios e até positivadas nos textos constitucionais, que podem ser vistas como verdades reconhecidas ou declarações genéricas do Direito na base da ética, política e pragmática. Elas costumam antecipar o consenso geral e, por isso, se prestam para formar "aspectos-padrão" a uma argumentação jurídica bem-sucedida (v.g.: bem-estar geral, proteção da boa-fé, natureza da coisa, princípio da prioridade, vedação da fraude à lei, dignidade humana, liberdade, igualdade, solidariedade etc.). Todavia, seria equivocado querer reduzir a base dos topoi da discussão jurídica apenas aos diversos princípios (explícitos ou implícitos) do Direito.

O raciocínio tópico mostra que os argumentos capazes de ganhar importância num processo jurídico não podem ser deduzidos de qualquer esquema lógico, mas surgem a partir de questões individuais coexistentes, não deduzíveis entre si. $\mathrm{Na}$ função de aportar aspectos relevantes para um problema jurídico que levem à formulação de perguntas concretas e hipóteses razoáveis, a tópica se presta para aumentar as chances de se chegar a uma decisão correta. Como ela também representa um processo complexo de raciocinar sobre os pontos pró e contra da solução de um problema, ela adquire seu real valor para o processo da decisão jurídica no ambiente do diálogo e da discussão (KRIELE, 1976).

Compete justamente à "arte da argumentação" saber destacar da imensa variedade de opiniões aqueles aspectos para os quais já existem fórmulas experimentadas, dotadas de um "efeito normativo sociológico", ou, pelo menos, sugestivas e manejáveis. Do enredo formado por estes topoi, o oponente do discurso só consegue se livrar 
se souber introduzir argumentos contrários pertinentes. Caso haja uma consolidação firme de um topos em "largas pré-compreensões sociais, constrói-se aqui uma premissa normativa para a conclusão retórica visada que propaga a solução almejada - se houver um suporte fático correspondente - com uma força de convicção perto da evidência" (ESSER, 1979, p. 13). Porém, o caráter de mero consenso de opinião deste tipo de premissa sempre será reproduzido também na respectiva dedução lógica, que não pode ser verificada mediante demonstração objetiva. O "julgar por verdadeiro" que forma a base da estratégia tópica jamais alcançará uma "qualidade ontológica" através do discurso. Antes, sua lógica reside "na fixação nas inferências plausíveis a partir das premissas aceitas" (ob. cit., p. 24).

Em resumo, a visão tópica do Direito pode ser compreendida como ênfase na sua dimensão argumentativa, isto é, a ideia de que as bases de uma decisão jurídica correta são postas no contexto de cada situação, através do intercâmbio de razões. Como inexistem neste processo de comunicação entre sujeitos verdades apodíticas que possam fundar uma solução indiscutível, há uma permanente (re)construção de soluções meramente plausíveis. A tópica pode auxiliar as partes neste processo dialógico de escolha de argumentos sobre os quais se assentará a decisão (GARCIA AMADO, 1987, p. 178).

\section{À GUISA DE CONCLUSÃO}

Do ponto de vista formal, os topoi apenas "estruturam o espaço" em que uma solução poderá se mover, sem que haja uma antecipação da decisão sobre a direção a ser tomada. Assim, o pensamento tópico é capaz de exercer apenas uma eficácia latente no raciocínio jurídico, que cumpre - em face da impossibilidade de se chegar a um conhecimento objetivo - um genuíno papel de comunicação entre as pessoas que buscam respostas à questão essencial da justiça e, para tanto, se deixam nortear pela necessidade prática de tornar o mundo mais controlável, tentando orientar e coordenar os seus atos. A tópica não pode simplesmente ignorar as ideias comuns de ordenamento que são representados pelo sistema jurídico; tendo em vista que estas normalmente são conservadas, ela apenas ganhará eficácia na medida em que conseguir tratar, de maneira interpretativa, novos pontos de vista, mantendo-se as concepções tradicionais. Nesse sentido, a interpretação do Direito é caracterizada por "entrelaçamentos inseparáveis entre processos dedutivos e inventivos" (LAUNHARDT, 2001, p. 145ss.).

Vale ressaltar que o estudo da retórica e da tópica não tem por objetivo a superação da tradicional forma de apresentar decisões jurídicas no Estado de Direito, que cumpre importante função pacificadora; antes, serve ao "esclarecimento metódico" do operador do Direito em formação. Assim, não faz muito sentido que uma pessoa fascinada pela retórica e tópica queira simplesmente abandonar as regras metodológicas e os elementos metódicos tradicionais da interpretação/aplicação do Direito; basta que o iniciado no raciocínio retórico-tópico desenvolva uma consciência mais aguçada e uma atitude autocrítica em relação ao trabalho jurídico diário, 
reconhecendo que certos dogmas da "ciência do Direito" até hoje cumprem, acima de tudo, a função de garantir o funcionamento das instituições do Estado Democrático de Direito.

Além disso, a reflexão retórico-tópica é capaz de fortalecer o espírito crítico-construtivo tanto do estudante quanto do estudioso do Direito, em relação a um efetivo controle da argumentação e fundamentação daqueles que decidem com base nas normas jurídicas vigentes, destacando, inclusive, o lado criativo e valorativo desta função. Por fim, seja dito àqueles que (ainda) sofrem com a pretensa "falta de cientificidade" do processo de interpretação e aplicação do Direito, que o próprio significado de ciência é extremamente elástico e que já os antigos filósofos, cujas teorias formaram a base de toda a civilização ocidental, reconheciam que as diferentes áreas da vida e da ação humana não podem ser analisadas e explicadas a partir dos mesmos modelos e conceitos de saber, conhecimento e verdade. Neste espírito, eles jamais menosprezaram os conhecimentos obtidos por dedução retórica em favor da dedução lógico-formal, que é típica das ciências naturais exatas.

Um bom exemplo é a questão da anulação de uma lei por violação do princípio da dignidade da pessoa humana (art. 1, III, CF). Em vez de querer traçar os limites da pretensa "moldura" (kelseniana) da norma extraída do texto constitucional, na qual a decisão do julgador seria completamente livre por não ser acessível ao controle "científico-racional" (em termos positivistas), ou de tentar descobrir o "verdadeiro conteúdo da norma" intencionado pelo legislador, através de uma pretensa "dedução" do sentido mediante operações lógicoconceituais, o intérprete inspirado pelo raciocínio retórico-tópico concentrar-se-ia na análise das figuras retóricas empregadas para fundamentar a decisão judicial em favor ou contra a alegada violação da dignidade, medindo o poder de convencimento dos argumentos e avaliando a coerência do discurso jurídico apresentado.

Agindo assim, ele, por um lado, não trataria a decisão como algo aleatório e contingente, mas, pelo outro, também não assumiria a atitude ingênua de acreditar na obtenção da decisão jurídica por meio de critérios objetivos, seguros e metodicamente previsíveis. Na verdade, a análise tópico-retórica do Direito enfrenta o "desafio de cultivar certos padrões de racionalidade e, ao mesmo tempo, evitar expectativas exageradas em relação à racionalidade das decisões" (LAUNHARDT, 2005, p. 3).

Por fim, vale lembrar que a decisão jurídica é produzida pelo intérprete/aplicação do Direito basicamente a partir de elementos textuais das regras e princípios incidentes, por figuras dogmáticas, doutrinas e decisões precedentes dos tribunais, além da consideração das prováveis consequências fáticas (econômicas, sociais e políticas) da decisão. Todos esses aspectos constituem argumentos apresentados no discurso de fundamentação da decisão, os quais podem ser avaliados a respeito de seu grau de ethos (qualidades pessoais de quem fala/escreve), pathos (provocação de emoções nos ouvintes/leitores) e logos (racionalidade do próprio discurso).

Além disso, a linha de raciocínio do autor deste discurso dificilmente seguirá padrões lógico-dedutivos, e 
tampouco metódicos, mas valer-se-á de figuras tópicas para justificar as valorações interpretativas imprescindíveis para chegar a sua conclusão, a exemplo da notória e permanente referência dos operadores do Direito brasileiro aos princípios constitucionais. Com certeza, esta análise retórico-tópica contribuirá bastante para uma melhor compreensão da dinâmica e da complexidade do processo de produção da decisão jurídica no Brasil.

\title{
THE IMPORTANCE OF RHETORIC AND TOPIC REASONING FOR A BETTER COMPREHENSION OF THE DYNAMIC OF LEGAL ARGUMENTATION IN CONTEMPORARY TIMES
}

\begin{abstract}
The article intends to investigate the origin and importance of rhetorical-topical reasoning, which can lead to a better comprehension of the processes of creation of legal decisions today. Through the study of rhetorics, that deals with the ways how a speech may persuade an audience about a particular subject, and topics, which aims to solve problems with the help of arguments supported by common sense or the opinion of authorities, it is possible to overcome the idea of the legal decision as a result of deductive reasoning by subsumption of facts to general standards. From Aristotle we get to the current meaning of rhetorics and topics, on the basis of authors like Viehweg, Perelman, Ballweg, Schlieffen, Kriele. Wieacker and Adeodato. Thus, it is intended to arouse interest to carry out further studies on the subject, in order to create a more reflective and critical self-image of the jurists on their work. A thinking inspired in rhetorics and topics also helps for better understanding of the legal decisions produced by the organs of Brazilian State, where not yet have been formed "hermeneutical minimum standards" that could turn more rational and predictable the acts of legal interpretation and application.
\end{abstract}

Keywords: Rhetorics; topics; legal interpretation; argumentation; syllogism, enthymeme.

\section{REFERÊNCIAS BIBLIOGRÁFICAS}

AARNIO, Aulis. Denkweisen der Rechtswissenschaft: Einführung in die Theorie der rechtswissenschaftlichen Forschung. Wien - New York: Springer, 1979 (a).

Linguistic philosophy and legal theory: some problems of legal argumentation. In: KRAWIETZ, W. et al. (eds.). Argumentation und Hermeneutik in der Jurisprudenz. Berlin: Duncker \& Humblot, 1979 (b), pp. 17-41. ACHTERBERG, Norbert. Argumentationsmängel als Fehlerquellen bei der Rechtsfindung. In: KRAWIETZ, W. et al. Argumentation und Hermeneutik in der Jurisprudenz. Berlin: Duncker \& Humblot, 1979, pp. 43-57.

ADEODATO, João Maurício. A retórica constitucional: sobre tolerância, direitos humanos e outros fundamentos éticos do direito positivo. São Paulo: Saraiva, 2009.

Filosofia do Direito: uma crítica à verdade na ética e na ciência. São Paulo: Saraiva, 1996.

O silogismo retórico (entimema) na argumentação judicial. In: Ética e retórica: para uma teoria da dogmática jurídica. São Paulo: Saraiva, 2002, pp. 261-283.

Uma teoria retórica da norma jurídica e do direito subjetivo. São Paulo: Noeses, 2011. 
ALEXY, Robert. Teoria da argumentação jurídica: a teoria do discurso racional como teoria da fundamentação jurídica. Trad.: Zilda H. S. Silva e Cláudia Toledo. 3. ed. Rio de Janeiro: Forense, 2011.

ARISTÓTELES. Ética a Nicômacos. Trad.: Mário da G. Kury. 4. ed. Brasília: UnB, 2001.

Retórica. Trad.: M. Alexandre Júnior. Lisboa: Casa da Moeda, 2005.

ATIENZA, Manuel. As razões do Direito. Trad.: M. Cupertino. São Paulo: Landy, 2002.

BALLWEG, Ottmar. Phronetik, Semiotik und Rhetorik. In: BALLWEG, O.; SEIBER, T.-M. (eds.). Rhetorische Rechtstheorie. Freiburg/München: Karl Alber, 1982, p. 27-71.

CANARIS, Claus-Wilhelm. Systemdenken und Systembegriff in der Jurisprudenz: entwickelt am Beispiel des deutschen Privatrechts. 2 ed. Berlin: Duncker\&Humblot, 1983.

CASTRO JÚNIOR, Torquato. A pragmática das nulidades e a teoria do ato jurídico inexistente. São Paulo: Noeses, 2009.

COING, Helmut. Grundzüge der Rechtsphilosophie. 5. Aufl. Berlin/New York: Walter de Gruyter, 1993.

ENGISCH, Karl. Introdução ao pensamento jurídico. Trad.: João B. Machado. 6. ed. Lisboa: Fundação Calouste Gulbenkian, 1983.

ESSER, Josef. Juristisches Argumentieren im Wandel des Rechtsfindungskonzepts unseres Jahrhunderts. Heidelberg: Carl Winter, 1979.

FERRAZ JÚNIOR, Tércio Sampaio. Introdução ao estudo do Direito: técnica, decisão, dominação. 2. ed. Sao Paulo: Atlas, 1994.

GADAMER, Hans-Georg. Hermeneutik II: Wahrheit und Methode: Ergänzungen, Register. 2. ed. Tübingen: Mohr, 1993.

GARCIA AMADO, Juan Antonio. Tópica, Derecho y método jurídico. Doxa, n. 4, Alicante, 1987, p. 161-188.

GAST, Wolfgang. Juristische Rhetorik 4. ed. Heidelberg: C. F. Müller, 2006.

HAFT, Fritjof. Juristische Hermeneutik und Rechtsrhetorik. In: HASSEMER, Winfried (ed.). Dimensionen der Hermeneutik: Arthur Kaufmann zum 60. Geburtstag. Heidelberg: R. v. Decker \& C. F. Müller, 1984, p. 91-101.

HENKEL, Heinrich. Einführung in die Rechtsphilosophie. München/Berlin: Beck, 1964.

HÖFFE, Otfried. Aristóteles. Trad.: Roberto H. Pich. Porto Alegre: Artmed, 2008.

HORN, Hans-Rudolf. Dimensionen der Demokratiefähigkeit. Archiv für Rechts- und Sozialphilosophie (ARSP), vol. 86, 2000, Heft 3, p. 400-411.

KANT, Immanuel. Kritik der Reinen Vernunft. 1787. Disponível em: www.sapientia.ch/E-Buecher/Philosophie. Acesso: jul. 2015. 
KRAWIETZ, Werner. Zum Paradigmenwechsel im juristischen Methodenstreit. In: KRAWIETZ, W. et al. (eds.). Argumentation und Hermeneutik in der Jurisprudenz. Berlin: Duncker \& Humblot, 1979, p. 113-152.

KRELL, Andreas J. Entre desdém na teoria e aprovação na prática: os métodos clássicos de interpretação jurídica. Revista Direito GV, n. 19, 2014, São Paulo, p. 295-317.

KREUZBAUER, Günther. Kleine Einführung in die Forschungsgeschichte der juristischen Argumentationstheorie. In: KREUZBAUER, G.; AUGENEDER, S. (eds.). Der juristische Streit: Recht zwischen Rhetorik, Argumentation und Dogmatik. Stuttgart: Franz Steiner, 2004, p. 9-25.

KRIELE, Martin. Theorie der Rechtsgewinnung: entwickelt am Problem der Verfassungsinterpretation. 2. ed. Berlin: Duncker \& Humblot, 1976.

LAUNHARDT, Agnes. Methodenlehre aus rechtsrethorischer Perspektive: Abschied von der Normativität? In: KRAWIETZ, W.; MORLOK, M. (eds.). Vom Scheitern und der Wiederbelebung juristischer Methodik im Rechtsalltag. Berlin: Duncker\&Humblot, 2001, p. 141-157.

Topik und Rhetorische Rechtstheorie: eine Untersuchung zu Rezeption und Relevanz der Rechtstheorie T. Viehwegs. Tese de Doutoramento da Faculdade de Direito da Univ. Heinrich Heine, Düsseldorf, 2005. Disponível em: http://docserv.uni-duesseldorf.de/servlets/DerivateServlet/Derivate-3244/1244.pdf.. Acesso: ago. 2015 .

MASTRONARDI, Philippe. Juristisches Denken: eine Einführung. Bern/Stuttgart/Wien: Haupt (UTB), 2001.

MÜLLER, Friedrich. Teoria estruturante do Direito. Trad.: Peter Naumann e Eurides A. de Souza. São Paulo: RT, 2008.

NEUMANN, Ulfrid. Juristische Methodenlehre und Theorie der juristischen Argumentation. In: KRAWIETZ, W.; MORLOK, M. (eds.). Vom Scheitern und der Wiederbelebung juristischer Methodik im Rechtsalltag. Berlin: Duncker \& Humblot, 2001, p. 239-255.

NEUMANN, Ulfrid. Recht als Struktur und Argumentation. Baden-Baden: Nomos, 2008.

PAVČNIK, Marijan. Juristisches Verstehen und Entscheiden - Vom Lebenssachverhalt zur Rechtsentscheidung: ein Beitrag zur Argumentation im Recht. Wien/New York: Springer, 1993.

Non-equivalent transformations in the law. In: KRAWIETZ, W. et al. (eds.). Argumentation und Hermeneutik in der Jurisprudenz. Berlin: Duncker \& Humblot, 1979, p. 163-176.

PERELMAN, Chaim. Lógica jurídica. Trad.: Virgínia K. Pupi. 2. ed. São Paulo: Martins Fontes, 2004.

Retóricas. Trad.: M. Ermatina Galvão. São Paulo: Martins Fontes, 1999.

PFORDTEN, Dietmar von der. Deskription, Evaluation, Präskription. Trialismus und Trifunktionalismus als sprachliche Grundlage von Ethik und Recht. Berlin: Duncker \& Humblot, 1993.

RODRIGUEZ, José Rodrigo. Como decidem as cortes? Para uma crítica do Direito (brasileiro). Rio de Janeiro: FGV, 2013.

ROESLER, Claudia Rosane. Theodor Viehweg e a ciência do Direito: tópica, discurso, racionalidade. Florianópolis: Momento Atual, 2004. 
SCHLIEFFEN, Katharina Gräfin von. Rhetorik und rechtsmethodologische Aufklärung. In: KRAWIETZ, W.; MORLOK, M. (eds.). Vom Scheitern und der Wiederbelebung juristischer Methodik im Rechtsalltag. Berlin: Duncker \& Humblot, 2001, p. 175-196.

SCHLIEFFEN, Katharina Gräfin von. Rhetorische Rechtstheorie. In: UEDING, Gert (ed.). Rhetorik: Begriff Geschichte - Internationalität. Tübingen: Max Niemeyer, 2005, p. 313-324.

SCHOPENHAUER, Artur. Como vencer um debate sem precisar ter razão: em 38 estratagemas (dialética erística). Trad.: D. Caldas e O. de Carvalho. São Paulo: Topbooks, 1997.

SCHRECKENBERGER, Waldemar. Rhetorik und Demokratie. Archiv für Rechts- und Sozialphilosophie ARSP, vol. 86, 2000, Heft 3, p. 367-399.

SENA JÚNIOR, Antiógenes Viana de. Os princípios constitucionais como topoi legitimadores no processo de decisao judicial: a utilizacao do principio da proporcionalidade. In: ADEODATO, J. M. (coord.). Dogmática jurídica e Direito subdesenvolvido: uma pesquisa pioneira sobre peculiaridades do Direito brasileiro. Rio de Janeiro: Lumen Juris, 2008, p. 213-254.

SMITH, Robin. Lógica. In: BARNES, J. (org.). Aristóteles. São Paulo: Ideias \& Letras, 2009.

STEIN, Erwin. Werte und Wertewandel in der Gesetzesanwendung des öffentlichen Rechts. In: ESSER, J:; STEIN, E. (eds.). Werte und Wertewandel in der Gesetzesanwendung. Frankfurt a.M., 1966, p. 40ss.

STRUCK, Gerhard. Topische Jurisprudenz. Frankfurt a.M.: Athenäum, 1971.

Zur Theorie der juristischen Argumentation. Berlin: Duncker \& Humblot, 1977.

TAMMELO, Ilmar. Rechtslogik und materiale Gerechtigkeit. Beiträge zur Rechtsphilosophie und zur Theorie des Völkerrechts. Frankfurt a.M.: Athenäum, 1971.

VIEHWEG, Theodor. Rechtsphilosophie und Rhetorische Rechtstheorie. Baden-Baden: Nomos, 1995.

Topik und Jurisprudenz: ein Beitrag zu rechtswissenschaftlichen Grundlagenforschung. 4. ed. München: C. H. Beck, 1969.

VILANOVA, Lourival. Sobre o conceito do Direito. In: Escritos jurídicos e filosóficos - I. São Paulo: Axis Mundi/IBET, 2003.

WEBER, Max. Wirtschaft und Gesellschaft. Grundriss der verstehenden Soziologie. 5. ed. (Ed.: J. Winckelmann). Tübingen: Mohr, 1980.

WIEACKER, Franz. Zur praktischen Leistung der Rechtsdogmatik. In: BUBNER, R. et al. (eds.). Hermeneutik und Dialektik - Festschrift für Hans-Georg Gadamer, Bd. II. Tübingen: Mohr, 1970, p. 311-336.

WOLFF, Hans J.; BACHOF, Otto; STOBER, Rolf. Direito Administrativo - Vol. 1. Trad.: António F.de Sousa. Lisboa: Fund. Calouste Gulbenkian, 2006.

ZIPPELIUS, Reinhold. Recht und Gerechtigkeit in der offenen Gesellschaft. 2. ed. Berlin: Duncker \& Humblot, 1996. 
Trabalho enviado em 20 de setembro de 2015. Aceito em 18 de outubro de 2015. 